Journal of Management \& Public Policy

Vol. 12, No. 2, June 2021, Pp. 4-26

ISSN 0976-0148 (Online) 0976-013X (Print)

DOI: https://doi.org/10.47914/jmpp.2021.v12i2.001

\title{
Engaging Pedagogical Strategies for Students in Teaching Sessions: A Suggestive Framework Blueprint
}

\section{Sheela Bhargava*}

\begin{abstract}
This study aims at understanding main reasons of disengagement in teaching session from students' perspective. It further examines what pedagogical methods and preparations can contribute to higher student engagement in teaching session both from teachers' and students' perspectives. The study was conducted through interpretative phenomenological analysis to identify and analyze the experiences of the respondents. Primary data was obtained via semi- structured interviews of participants from Delhi NCR, India. The results are reflected in the form of superordinate themes that emerged through analyzing the responses of participants. Based on exploratory details, some of the themes related to students' disengagement were identified as insufficient interpersonal communication, lack of real-time application, dearth of empathy and dubious personal behaviour of teacher. The findings also define the Action Plan for teachers for enhancing student engagement in teaching session.
\end{abstract}

KEYWORDS: Student engagement/disengagement, Higher education, Pedagogical strategies, interpretative phenomenological analysis,

\footnotetext{
*Associate Professor, Lal Bahadur Shastri Institute of Management, New Delhi, India E-mail: sheela.bhargava@gmail.com
} 


\section{INTRODUCTION}

The notion of student engagement has gained new insights in higher education sector in last two decades. Student engagement is attracting more attention than student retention for research studies nowadays (Tight, 2019). Student engagement is a complex process that defines student experiences like what they do, feel and think while learning, it also focuses on how teachers can enhance these student experiences in instructional settings (Zepke, 2017). In modern times, student engagement has been built around the hopeful goal of enhancing all abilities of students to learn and become lifelong learners in a knowledge-based society. One of the most important issues currently being faced by higher education community is student engagement (Leach, 2016).

Engagement level is predicted on this belief that learning improves whenever students are interested, inquisitive and inspired. Learning may start to suffer whenever students are disaffected, dispassionate or in other words are 'disengaged'. Evidence from research by Hazel Christie \& Nina Morris (2019) suggests that wider insights about student engagement depends on recognizing role of students' investment in learning process. Ongoing discussions about its complex nature have made it an enigma for researchers and educators to a certain degree (Kahn, 2014; Zepke, 2018). Ingrained belief pertaining to engagement is that learning experiences that are interesting and have substantive meaning to students eventually lead to superior academic achievement (Schlechty, 2004).

In comparison to their unmotivated and un-engaged peers, students that are motivated and engaged in learning are better behaved and tend to perform considerably greater academically (Fredricks et al., 2004). Student engagement is influenced and impacted by many contextual factors, it does not evolve in vacuum, so it becomes imperative to consider these wider influences (Quin, 2017; Appleton et al., 2008; Kahu, 2013). Students are more engaged when relevant and realistic content is provided and they are able to apply what they learn (Bolliger and Martin, 2020). Higher Education institutions are beginning to create more engaging experiences for students. These measures are based on the assumptions and ideas that student who are more engaged and contribute actively to their learning environments are more likely to repeat the same to an organizational work setting in the form of employee engagement and are more likely to succeed in their professions. 
Frequently, educators imagine that using a specific technological tool or application shall lead to change in students' learning experiences and outcomes. However, it's not the technology that really matters, but the pedagogical approach how transactions, tasks and activities have been designed and incorporated by teacher to promote learning and engage students. As technology can both impede or hasten meaningful learning and student engagement, this technology-mediated learning environment should be properly investigated (Perini, 2016).

Around whole process of student engagement, role of teacher is at center-stage. It is the teacher that has decide how to blend conventional pedagogical tools with technologyenabled learning tools to generate a more meaningful environment that promotes high engagement resulting in improved learning and retention. Teachers are not considered as 'lone riders' now but are deemed as multi-talented professionals that work in collaborative networks (Martin et.al., 2018).

So far, interrelationship between student engagement and role of teacher in deciding the use of blended teaching methods from teachers' perspective has been relatively unexplored. This research was carried out to understand the crucial reasons for student disengagement in teaching sessions from students' perspectives. Additionally, it discusses the pedagogical methods contributing towards motivating and engaging students as well as certain measures are recommended for boosting student engagement from both teachers' and students' perspectives. The context of study were teachers teaching Management and Information Technology (IT) courses in higher education institutions in New Delhi, India.

The study focuses on following three research questions:

RQ1. From students' perspective, what are the main reasons of disengagement in teaching session?

RQ2. From teachers' perspective, what pedagogical methods and preparations can contribute to higher student engagement in teaching session? 
RQ3. From students' perspective, what pedagogical methods and preparations can contribute to their higher engagement in teaching session?

\section{LITERATURE REVIEW}

\section{Student Engagement}

For last seven decades, interest in student engagement has been on continuous rise (Axelson \& Flick, 2011; Kuh, 2009). Since then, student engagement studies have progressed considerably, significant contribution was of Astin's (1984) formative work regarding impact of the quality and quantity of students' effort on learning. Subsequently more research discussed individual dispositions and environmental conditions that contribute towards student engagement (Martin et al., 2017; Bakker et al., 2015; Pellas, 2014; Gilboy et al., 2015). Student engagement is a broad phenomenon, and its definitions are ingrained in psychological, cultural and social perspectives (Fredricks et al., 2004; Wimpenny \& SavinBaden, 2013; Zepke \& Leach, 2010). In any teaching session, student engagement is the dynamic process that involves students' motivation and personal acts of attention including their interactions with peers and teachers (Lawson and Lawson, 2013). Numerous student engagement models portray engagement as psycho-social complex process. These models have established the engagement process into three areas (Lam et al., 2012; Kahu, 2013) as given in Table I.

Table I: Student Engagement Variables and their examples

\begin{tabular}{|c|c|c|}
\hline $\begin{array}{l}\text { Factors influencing } \\
\text { engagement }\end{array}$ & student & $\begin{array}{l}\text { Curriculum, technological tools \& } \\
\text { pedagogical methods and institutional } \\
\text { culture }\end{array}$ \\
\hline $\begin{array}{l}\text { Main Indicators } \\
\text { engagement }\end{array}$ & student & $\begin{array}{l}\text { Meaningful processing of information, } \\
\text { interest in learning, interactions taking } \\
\text { place with } \\
\text { instructors and peers }\end{array}$ \\
\hline $\begin{array}{l}\text { Expected Outcomes of } \\
\text { engagement }\end{array}$ & student & $\begin{array}{l}\text { Superior academic achievement, personal } \\
\text { growth and retention }\end{array}$ \\
\hline
\end{tabular}


Engagement is the energy and efforts employed by students amongst their learning community and it can be observed through cognitive, behavioral or affective indicators across a continuum (Fredricks et al. 2004; Reschly and Christenson, 2012); Wang \& Holcombe 2010). It is also considered as a meta-construct that comprises of four components, namely behavioral, emotional, cognitive and agentic engagement (Fredricks and McColskey, 2012; Reeve, 2012) (please see Table II).

\section{Table II: Facets of Student Engagement}

\begin{tabular}{|l|l|}
\hline $\begin{array}{l}\text { Facets of Student } \\
\text { Engagement }\end{array}$ & Meaning \\
\hline Behavioral Engagement & $\begin{array}{l}\text { It includes the idea of student involvement and } \\
\text { participation in various academic activities. It is } \\
\text { suggested that to be behaviorally engaged, a student } \\
\text { have to comply with norms of teaching session and } \\
\text { refrain from disruptive behavior. }\end{array}$ \\
\hline Emotional Engagement & \begin{tabular}{l} 
It encompasses the positive and negative reactions of \\
students with their teaching session mates and \\
teachers. It is also related to the feeling of \\
belongingness and importance associated with \\
institution by the student. \\
It is reflected with the extent of investment done by \\
student in learning. Here, investment indicates the \\
exertion of efforts put in for solving complex academic \\
problems and skill development. \\
\hline Cognitive Engagement
\end{tabular} \\
$\begin{array}{l}\text { It refers to the constructive contribution done by } \\
\text { student in terms of taking initiatives that contribute } \\
\text { towards learning and teaching. Students are considered } \\
\text { as an active agent in the learning process, }\end{array}$ \\
\hline
\end{tabular}




\section{Influence of Student Engagement in Meaningful Learning}

Engagement can be expressed as how actively a student is involved in a learning activity (Christenson et al., 2012). Students become builders of their own learning environments through increasing their engagement in teaching-learning process and they receive greater support from teachers (Matos et al., 2018). Authentic learning and personal development outcomes can be positively impacted by student engagement (Carini et al., 2006). Many research have specified that highly engaged students depict better grade point averages (GPAs), higher graduation rates, higher levels of educational satisfaction, better retention and persistence (Kuh et al., 2005, Astin and Sax, 1998).

\section{Teacher as Agent}

In higher education, predominantly learning is not expected to be limited to simply acquiring new information and processes. Thus, the teaching process should emphasize on developing students' capability to think about their subject from multiple qualitative ways, so transmissive teaching that promotes rote learning would not be adequate for developing critical thinking and intellectual skills essential for students. The explicit method which a teacher chooses to employ a specific pedagogical method or technological tool will depend on the distinct contextual circumstances, for example, the type of learning activity and expected learning outcomes etc. Therefore, the wisdom of teacher is very crucial in deciding the right blend of conventional pedagogy and technological tools.

\section{METHOD}

The research approach employed for the study was interpretative phenomenological analysis (IPA) technique. IPA is a qualitative research approach applied in exploring and understanding the lived experiences of a particular phenomenon (Saini and Chaudhary, 2019; Eatough and Smith, 2008; Smith, 2004; Pringle et al., 2011). This methodology involves detailed assessment of life of participants, their experiences pertaining to a specific phenomenon, how they derive meaning attached to the experiences (Smith, 2004). IPA studies attempt to reveal not only shared experiences, but they also focus on disclosing differences in experiences. This helps researchers in attaining in-depth insights and gives unambiguous knowledge of participants' perceptions and understandings associated to a specific group, in that way it 
does not generate a generalized theory related to whole population (Pietkiewicz and Smith, 2014).

\section{Participants}

For the study, participants were from Delhi and National Capital Region (NCR) in India. For any qualitative research, the identification of participants is very crucial. It is mostly done by selecting people and place as per a specific criterion. Only those are selected who can assist in better knowledge regarding the central phenomenon (Creswell, 2013). In IPA studies, generally purposive sampling method is used for selection of research participants. The small sample size which is broadly homogenous in nature can provide adequate perspective in a given context (VanScoy and Evenstad, 2015). Small sample sizes ranging from 1 to 15 or more are mostly undertaken in IPA studies (Smith and Osborn, 2008). Additionally, size of participants can be between 2 and 25 in a phenomenological research, (Chaudhary et al., 2019; Creswell, 2012). To this end, 11 teachers teaching in Higher Education Institutions (HEI) and 16 students pursuing Post Graduate Diploma in Management (PGDM) courses (all were in second year of post- graduation) in HEls located in Delhi and NCR were selected for study. Out of the 11 teachers, seven were females and four were males. Out of 16 students, eight were males and eight were females (Table- III). Main reason for collecting data from two different categories of participants, i.e., teacher and student was to understand the issue of student engagement from both their perspectives. This would help in a more in-depth understanding of research problem.

Table III: Profile of Participants

\begin{tabular}{|l|l|l|l|}
\hline Participant & Gender & $\begin{array}{l}\text { Age } \\
\text { (in years) }\end{array}$ & Area of specialization \\
\hline Teacher 1 & Female & 34 & Marketing \\
\hline Teacher 2 & Female & 42 & Economics \\
\hline Teacher 3 & Female & 37 & Human Resources \\
\hline Teacher 4 & Female & 38 & Human Resources \\
\hline Teacher 5 & Female & 50 & Operations Research \\
\hline Teacher 6 & Female & 33 & International Business \\
\hline
\end{tabular}




\begin{tabular}{|c|c|c|c|}
\hline Teacher 7 & Female & 46 & Finance \\
\hline Teacher 8 & Male & 44 & Business Analytics \\
\hline Teacher 9 & Male & 45 & $\begin{array}{l}\text { Logistics and Supply-chain } \\
\text { Management }\end{array}$ \\
\hline Teacher 10 & Male & 54 & Information Technology \\
\hline Teacher 11 & Male & 36 & Information Technology \\
\hline Student 1 & Female & 22 & Marketing \\
\hline Student 2 & Female & 22 & Marketing \\
\hline aStudent 3 & Female & 23 & Marketing \\
\hline Student 4 & Female & 22 & Finance \\
\hline Student 5 & Female & 25 & Finance \\
\hline Student 6 & Female & 22 & Finance \\
\hline Student 7 & Female & 22 & International Business \\
\hline Student 8 & Female & 23 & Business Analytics \\
\hline Student 9 & Male & 22 & Business Analytics \\
\hline Student 10 & Male & 22 & Operations Management \\
\hline Student 11 & Male & 24 & Operations Management \\
\hline Student 12 & Male & 25 & Operations Management \\
\hline Student 13 & Male & 23 & Human Resource Management \\
\hline Student 14 & Male & 22 & Human Resource Management \\
\hline Student 15 & Male & 25 & Information Technology \\
\hline Student 16 & Male & 23 & Information Technology \\
\hline
\end{tabular}

Out of the 11 teachers, seven were females and four were males. Out of 16 students, eight were males and eight were females (Table- III). Main reason for collecting data from two different categories of participants, i.e., teacher and student was to understand the issue of student engagement from both their perspectives. This would help in a more in-depth understanding of research problem. 


\section{DATA COLLECTION AND SAMPLE}

In interpretative phenomenological analysis studies, data is mainly collected through semistructured interviews (Smith et al., 2009). Primary data was collected via semi-structured interviews of participants. Semi-structured interviews provided the researchers an opportunity to have an in-depth engagement with each participant as an individual case and in detailed examination of their differences and similarities, i.e., the divergences and convergences. Researchers undertook prior approvals from the respective Deans of various departments and then had sent requests for personal appointments to participants (both teachers and students). For data collection, an interview schedule having fifteen questions and their possible prompts was formed. The inputs of five senior faculty members as experts in the field were obtained to verify the reliability and validity of questions' checklist and suggested modifications were incorporated. Few questions were like, what are possible reasons of student disengagement, how to enhance student engagement and role of team interventions in improving engagement etc. For each participant, two interviews consisting of 30 and 60 minutes were organized with each participant. More than one interview gave participants the opportunity to reflect on questions over time which sometimes resulted in additional insights. As IPA is committed to in-depth analysis of cases rather than jumping to generalizations (Smith, 2003), researchers could also occasionally recover missed chances to probe interesting responses from participants when they were initially first mentioned. Responses of all interviews were systematically recorded and further transcribed by researchers. For authentication, transcriptions were sent to participants later and they were further encouraged to contribute any additional reflections.

Non-probability purposive sampling methods was used for selecting the participants. As it has been stated in many previous researches that in qualitative research, typically purposive sampling is used to select and identify the information-rich cases (Patton, 2002; Etikan et al., 2016). However, in this study, maximum variation sampling was intentionally planned, according to it, samples of individuals or cases that differ in a feature or trait should be selected (Creswell, 2003). So, an effort was made to select those HEI teachers and students that have different specialization areas as background. For protecting anonymity of participants, their actual names are not mentioned. Reason for selecting both student and 
teacher as sampling unit was that both these categories of individuals have profound effect on student engagement.

\section{DATA ANALYSIS}

Thematic analysis method was followed for analysing collected data by coding the theoretical concepts that appeared repeatedly, thereby avoiding difficulty of circularity (Dana and Dumez, 2015). In this process, participants' answers were thoroughly read and analysed for identifying key themes that gave profound insights into each participant's viewpoint on student engagement. Further, these notes were transcribed in a meaningful way to find out the exploratory themes arising out of data and subsequently the central themes that evolved constantly through the analysis of interview transcripts. This process of data analysis is a significant and flexible method which helps researcher in achieving intricate descriptive results (Holloway and Todres, 2003). Per theme, excerpts obtained from three to four participants are appropriate for any sample size that is greater than eight (Smith, 2011). Under the detailed multi-stage data analysis process, focus was on analyzing a single participant's data at a time and then moving from the descriptive analysis to interpretive analysis through initially capturing participants' initial thought, in that way generating tentative themes. To ensure accuracy, the researchers also listened to recording of interviews and matched the same with the transcript, the emerging empirical comments were written in a column of the coding sheet. The process proceeded from tabulating generic exploratory comments of participants to emergent themes and further to superordinate themes for every participant. The same process was repeated for each participant. The process proceeded from tabulating generic exploratory comments of participants to emergent themes and further to superordinate themes for every participant. The same process was repeated for each participant.

\section{RESEARCH FINDINGS}

The emergent themes rising out of exploratory comments from data analysis were clustered in four super-ordinate themes. The superordinate themes are:

- reasons for student disengagement

- pre-session preparation by teachers

- in-teaching session activities by teachers 
- $\quad$ post-session preparation by teachers

These four superordinate themes give a descriptive and vivid account of the participant's subjective experience related to engagement in teaching-learning.

\section{Reasons of students' disengagement}

The 'reasons of student disengagement' superordinate theme relates to the student participants' views related to their past self while they were attending teaching sessions conducted by teachers. It demonstrates their insight into why they are less or not interested in a teaching session due to which it leads to their inability to fully grasp the subject contents. Some sample responses are discussed below:

\section{Sample-1}

'The teacher was teaching in such a boring manner that it was making me sleep, I tried not to dodge off, but everything was so general that I decided to switch off my mind. But when I was preparing for the subject quiz test, I really hated myself for not listening in teaching session. I could not understand the chapters at all.' (Student Participant 1) Student participant 1 here acknowledges why he was not attentive in teaching session even if he understood the detrimental effect of his actions later.

\section{Sample-2}

'I am a bit more talkative and probably more sociable. I can talk to any girl or boy, but here my teacher's now is speaking on and on without bothering whether we are understanding or not. Feel if they talked to us, we would understand without any problems and stuff so. It may have helped me to think also.' (Student Participant 4) Student Participant 4's response shows how interactions between teacher and student might have played a greater role in comprehending and understanding the subject content by student. Based on further analysis, it can be extrapolated that there are many reasons for students to be inattentive and disengaged in teaching session. After transcribing responses of teachers and students, the reasons for students' disengagement were realized and are categorized as sub-themes (Table IV). 
Table IV: Superordinate Sub-themes related to Students' Disengagement

\begin{tabular}{|c|c|}
\hline $\begin{array}{l}\text { Superordinate Sub- } \\
\text { themes }\end{array}$ & Exploratory Details \\
\hline $\begin{array}{l}\text { Insufficient } \\
\text { interpersonal } \\
\text { communication }\end{array}$ & $\begin{array}{l}\text { - When there is very less or no interaction between } \\
\text { teacher and students while teaching. } \\
\text { able to understand the content due to which they } \\
\text { become disengaged. } \\
\text { - When only lecture mode of teaching is used with } \\
\text { least interaction with students. }\end{array}$ \\
\hline $\begin{array}{l}\text { Lack of real- } \\
\text { time } \\
\text { application }\end{array}$ & $\begin{array}{l}\text { - When teachers don't use examples (real-time or may be } \\
\text { hypothetical) for explaining any topic. } \\
\text { - Cannot relate with examples given by teachers. }\end{array}$ \\
\hline $\begin{array}{l}\text { Instructor's } \\
\text { monotonous teaching } \\
\text { style }\end{array}$ & $\begin{array}{l}\text { - When teachers only read the text written on PPTs (Power } \\
\text { Point Slides) for teaching a topic and speak in a } \\
\text { monotonous tone. } \\
\text { - Teaching style and content is not interesting. } \\
\text { their lectures. } \\
\text { - When teachers snub students for asking questions, they } \\
\text { become passive listeners which gradually leads to } \\
\text { boredom. }\end{array}$ \\
\hline $\begin{array}{l}\text { Unable to } \\
\text { reduce } \\
\text { complexity }\end{array}$ & $\begin{array}{l}\text { - Content is difficult to understand as it is explained in } \\
\text { complex way (not easy way). } \\
\text { - When teacher spend more time in discussing topics that } \\
\text { are totally unrelated to the subject. }\end{array}$ \\
\hline
\end{tabular}




\begin{tabular}{|c|c|}
\hline Dearth of empathy & $\begin{array}{l}\text { - When teacher is generally very critical about students' } \\
\text { responses and behaviour. } \\
\text { - When teachers are too strict and they are not ready to } \\
\text { listen to anything indirectly related to the subject. } \\
\text { - When teacher does not listen to the } \\
\text { professional/personal problems cited by students. }\end{array}$ \\
\hline $\begin{array}{l}\text { Dubious personal } \\
\text { behaviour of Teacher }\end{array}$ & $\begin{array}{l}\text { - When teacher gets angry very frequently in teaching } \\
\text { session. } \\
\text { - When teachers frequently use their mobile phones for } \\
\text { non- academic purposes in teaching session. } \\
\text { teaching session. }\end{array}$ \\
\hline Impassive attitude & $\begin{array}{l}\text { - When teacher is not bothered about student attendance } \\
\text { in teaching session. } \\
\text { - When teachers speak in very low volume. }\end{array}$ \\
\hline Tolerating indiscipline & $\begin{array}{l}\text { - Distraction due to mobile phones. When teachers do not } \\
\text { emphasize about non-usage of mobile phones by } \\
\text { students in teaching session, the students keep their } \\
\text { mobiles in front of them and frequently look into them } \\
\text { to be aware about incoming calls and messages leading } \\
\text { to lack of concentration towards teaching topic. }\end{array}$ \\
\hline
\end{tabular}


Many factors can influence how engaged students are in teaching session such as how discussion flows are managed, an instructor's teaching style, or contents related to the day's chosen course materials. But importantly, students' effective engagement requires that teachers should actively seek to create that type of conditions that foster participating reactions. Suggestions for encouraging Teachers to Improve Student Engagement For questions regarding what factors and pedagogical tools can heighten student engagement in teaching sessions, participants' opinions indicated that numerous activities need to be conducted by teachers before undertaking a teaching session, during the sessions and after completion (post- sessions) also. This evidently signifies that student engagement can be augmented through effective planning regarding which activities should be conducted prior to the teaching session, in- teaching session activities and post-session activities. The findings based on analysis of participants' transcripts are presented in the form of a matrix in Table-V. This matrix can be used as a template to formulate an action plan for enhancing student engagement during teaching sessions.

Table -V: Action Plan for Enhancing Student Engagement in Teaching Session

\begin{tabular}{|c|c|c|c|}
\hline $\begin{array}{l}\text { Superordinat } \\
\text { e Themes }\end{array}$ & \multicolumn{3}{|c|}{$\begin{array}{l}\text { Suggestive Actions based on Exploratory } \\
\text { Comments }\end{array}$} \\
\hline $\begin{array}{l}\text { Activities to } \\
\text { be } \\
\text { Conducted } \\
\text { by } \\
\text { Teacher }\end{array}$ & $\begin{array}{l}\text { Conduct } \\
\text { Regularly/Freque } \\
\text { ntly }\end{array}$ & Conduct Sometimes & Avoid/Never \\
\hline $\begin{array}{l}\text { Pre-Session } \\
\text { Preparation } \\
\text { for enhancing } \\
\text { Student } \\
\text { Engagement }\end{array}$ & $\begin{array}{l}\text { - Prepare the } \\
\text { session thoroughly } \\
\text { and make deliberate } \\
\text { efforts for making } \\
\text { the session } \\
\text { interesting by pre- } \\
\text { deciding the } \\
\text { pedagogical tools to }\end{array}$ & $\begin{array}{l}\text { - Some general } \\
\text { advice to all students } \\
\text { for personal and } \\
\text { professional } \\
\text { development. } \\
\text { - Personal advice for } \\
\text { professional } \\
\text { development of }\end{array}$ & $\begin{array}{l}\text { - Go unprepared in } \\
\text { teaching session for } \\
\text { conducting } \\
\text { session. }\end{array}$ \\
\hline
\end{tabular}




\begin{tabular}{|c|c|c|c|}
\hline & $\begin{array}{l}\text { be used for it. } \\
\text { - Update yourself } \\
\text { (teacher) with } \\
\text { latest news and } \\
\text { trends for } \\
\text { correlating with } \\
\text { teaching content. } \\
\text { - Look for and } \\
\text { collect some real- } \\
\text { life examples } \\
\text { related to the topic } \\
\text { to be taught in } \\
\text { teaching session. }\end{array}$ & $\begin{array}{l}\text { student can also be } \\
\text { given by the teacher. }\end{array}$ & \\
\hline & $\begin{array}{l}\text { - Try to address } \\
\text { students by their } \\
\text { name (memorize } \\
\text { their } \\
\text { names in initial few } \\
\text { sessions). }\end{array}$ & $\begin{array}{l}\text { - Sometimes ask } \\
\text { students which } \\
\text { activity (list some } \\
\text { activities to choose } \\
\text { from) they }\end{array}$ & $\begin{array}{l}\text { - Make fun of the } \\
\text { answer given by a } \\
\text { student. }\end{array}$ \\
\hline $\begin{array}{l}\text { In-Teaching } \\
\text { session } \\
\text { Activities } \\
\text { enhancing } \\
\text { Student } \\
\text { Engagement }\end{array}$ & $\begin{array}{l}\text { - Correlate subject } \\
\text { topics to some kind } \\
\text { of news prevalent } \\
\text { during current time } \\
\text { period. } \\
\text { - Inculcate active } \\
\text { listening by using } \\
\text { relevant real-life } \\
\text { examples to which } \\
\text { students can } \\
\text { connect easily. } \\
\text { - Acknowledge the }\end{array}$ & $\begin{array}{l}\text { would prefer to } \\
\text { carry out in } \\
\text { teaching session } \\
\text { for understanding a } \\
\text { topic. } \\
\text { - Make use of group } \\
\text { activity for explaining a } \\
\text { topic, this may help in } \\
\text { experiential learning } \\
\text { also. } \\
\text { - Use a story to } \\
\text { elaborate and explain }\end{array}$ & $\begin{array}{l}\text { - Ridicule a } \\
\text { student. } \\
\text { - Make personal } \\
\text { remarks to } \\
\text { students. } \\
\text { - Criticize their } \\
\text { family } \\
\text { background. } \\
\text { - Become too } \\
\text { lenient due to } \\
\text { which indiscipline } \\
\text { may prevail in }\end{array}$ \\
\hline
\end{tabular}




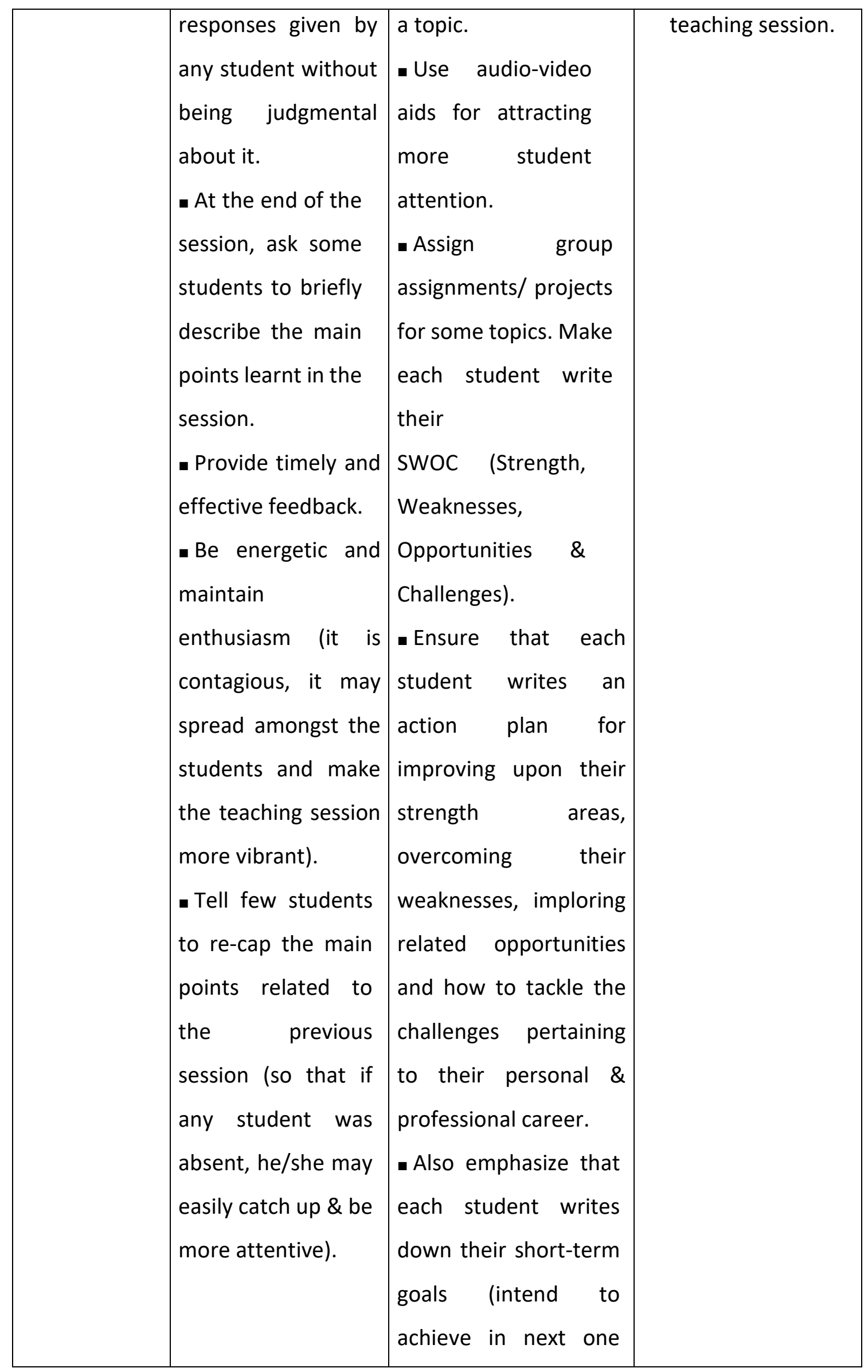




\begin{tabular}{|c|c|c|c|}
\hline & & $\begin{array}{l}\text { year) and long-term } \\
\text { goals (intend to } \\
\text { achieve in next 3-5 } \\
\text { years) on a piece of } \\
\text { paper or on their } \\
\text { electronic device and } \\
\text { save the } \\
\text { document for } \\
\text { frequent future } \\
\text { reference. }\end{array}$ & \\
\hline $\begin{array}{l}\text { Post-Session } \\
\text { Activities fo } \\
\text { enhancing } \\
\text { Student } \\
\text { Engagement }\end{array}$ & $\begin{array}{l}\text { - Keep taking } \\
\text { informal feedback } \\
\text { from few students } \\
\text { after the session. } \\
\text { - Reflect and try to } \\
\text { analyze whether } \\
\text { the session could } \\
\text { be made more } \\
\text { interesting and } \\
\text { effective. } \\
\text { - Update yourself } \\
\text { (faculty) with } \\
\text { latest news and } \\
\text { trends. }\end{array}$ & $\begin{array}{l}\text { - Inquire about } \\
\text { personal problem of } \\
\text { student (if you find } \\
\text { something unusual in } \\
\text { their behaviour). }\end{array}$ & $\begin{array}{l}\text { - Being partial to } \\
\text { a/few students. } \\
\text { - Back-biting about } \\
\text { some student or peer } \\
\text { or any other } \\
\text { organizational } \\
\text { member. }\end{array}$ \\
\hline
\end{tabular}




\section{SUGGESTIONS FOR ACADEMIC ADMINISTRATORS FOR ENCOURAGING TEACHERS TO IMPROVE STUDENT ENGAGEMENT}

The answers of participants also stated various propositions for academic administrators such as the top management officials, director and other administrative staff members that can result in encouraging teachers to improve student engagement. The themes arising out of these are depicted in Table VI.

Table VI: Themes based on Suggestions for Academic Administrators for Encouraging Teachers to Improve Student Engagement

\begin{tabular}{|c|c|}
\hline Superordinate Themes & Exploratory Details \\
\hline $\begin{array}{l}\text { Faculty Development } \\
\text { Programs }\end{array}$ & $\begin{array}{l}\text { - Organize faculty development programs and } \\
\text { also provide opportunities for training teachers } \\
\text { for focusing on student engagement. }\end{array}$ \\
\hline $\begin{array}{l}\text { Modelling High Engaging } \\
\text { Teachers }\end{array}$ & $\begin{array}{l}\text { - Encourage teachers to attend few sessions } \\
\text { conducted by teachers having high student } \\
\text { engagement in teaching session. }\end{array}$ \\
\hline $\begin{array}{l}\text { Student Engagement Level } \\
\text { as a criterion for } \\
\text { Performance Appraisal }\end{array}$ & $\begin{array}{l}\text { - Make student engagement an inherent part of } \\
\text { teachers' performance appraisal and their } \\
\text { improvement plan. }\end{array}$ \\
\hline Engagement & $\begin{array}{l}\text { - Conduct student survey to assess each } \\
\text { teacher's student engagement level (for } \\
\text { example-high, medium or low). }\end{array}$ \\
\hline $\begin{array}{l}\text { Encourage 'Backward } \\
\text { Design Method' }\end{array}$ & $\begin{array}{l}\text { - Encourage 'Backward Design Method' for } \\
\text { preparing for a teaching session. Backward } \\
\text { design is an educational curriculum designing } \\
\text { method by setting goals prior to choosing forms } \\
\text { of assessment and instructional methods. }\end{array}$ \\
\hline
\end{tabular}

\section{CONCLUSION}

Student engagement benefits not only students but is also crucial for higher education institutions and their stakeholders. The present study investigated the perspectives and 
reflections of students and teachers in magnifying student engagement in HEls. Important factors in engagement dynamics have been identified, based on findings from this research, appropriate technological interventions and pedagogical strategies can be designed. As teachers and institutions are putting many practical strategies in action, the scope of student engagement is likely to increase more in near future. It enables students with capability to acquie and practice essential skills to build successful future. Experts agree that student engagement leads to imparting knowledge better and promotes values of ownership amongst students. They further iterate that engagement during the teaching-learning process develops a superior sense of responsibility while contributing towards developing communication skills of students and enriching their professional skills as well. It fosters better relationships with other students and faculty also. As a result, it improves interpersonal relations in an educational setting thereby honing students' personality and skills that are vital for their professional development. The teachers should understand this fact that every single opportunity to engage students is unique in itself and it needs to be tailored accordingly. Nowadays, several institutions have adopted emerging technologies like student engagement portals and apps to improve engagement. These technological applications can help teachers and educational administrators in monitoring students' current performance, predict potential concerns, and prepare workable solutions for strategically advanced engagement of students.

\section{LIMITATIONS OF PRESENT STUDY AND SUGGESTIONS FOR FUTURE RESEARCH}

The present qualitative research used only interviews as primary data source for study. Moreover, it followed a perpendicular approach instead of adopting a wider approach that could have included more categories of educational institutions. Therefore, the results cannot be generalized. However, in context of student engagement in HEI students, the research study presents valuable insights that may further contribute towards more extensive research on same topic. The factors identified in this study can be included in creating a scale of measurement for student engagement. The formation of such scale would be highly beneficial for stakeholders related to field of higher education in general. The particular impact of technological interventions on student engagement could also be examined in future. 


\section{REFERENCES}

Appleton, J. J., Christenson, S. L. and Furlong, M. J. (2008). Student engagement with school: Critical conceptual and methodological issues of construct. Psychology in Schools, 45 (5), 369-386.

Astin, A. W. (1984). Student involvement: A developmental theory for higher education. Journal of College Student. Personnel Psychology. 25 (4), 297-308.

Astin, A. W. and Sax, L. J. (1998). How undergraduates are affected by service participation. Journal of College Student Development, 39 (3), 251-263.

Axelson, R. D. and Flick, A. (2010). Defining student engagement. Change: The Magazine of Higher Learning, 43 (1), 38-43.

Bakker, A. B., Sanz Vergel, A.I.S. and Kuntz, J. (2015). Student engagement and performance: A weekly diary study on the role of openness. Motivation and Emotion, 39 (1), 49-62.

Bolliger, D.U. and Martin, F. (2020). Factors underlying the perceived importance of online student engagement strategies. Journal of Applied Research in Higher Education, Vol. ahead-of- print No. ahead-of-print. https://doi.org/10.1108/JARHE-02-2020-0045

Carini, R. M., Kuh, G. D. and Klein, S. P. (2006). Student engagement and student learning: Testing the linkages. Research in Higher Education, 47 (1), 1-32.

Chaudhary, N.S., Phoolka, S., Sengar, R. and Pande, S. (2019). Whistle blowing in Indian higher education sector: A qualitative study. International Journal of Learning and Change, $11(2), 145-168$.

Christenson, S. L., Reschly, A. L., and Wylie, C. (Eds.) (2012). Handbook of Research on Student Engagement. Boston: Springer.

Creswell, J.W. (2003). Research design: Qualitative \& quantitative approaches. London: Sage.

Creswell, J. W. (2012). Educational research: Planning, conducting and evaluating quantitative and qualitative research, 4th Ed., Boston, MA: Pearson.

Creswell, J.W. (2013). Qualitative inquiry and research design: Choosing among five approaches., Los Angeles, CA: Sage

Dana, L. P. and Dumez, H. (2015). Qualitative research revisited: epistemology of a comprehensive approach. International Journal of Entrepreneurship and Small Business, 26 (2), 154-170.

Eatough, V. and Smith, J. A. (2008). Interpretative phenomenological analysis. The Sage Handbook of Qualitative Research in Psychology, Vol. 179, pp. 194. 
Etikan, I., Musa, S. A. and Alkassim, R. S. (2016). Comparison of convenience sampling and purposive sampling. American Journal of Theoretical and Applied Statistics, 5 (1), 1- 4.

Fredricks, J. A., Blumenfeld, P. C., and Paris, A. H. (2004). School engagement: potential of the concepts, state of the evidence. Review of Educational Research, 74 (1), 59-109.

Fredricks, J., and Mccolskey, W. (2012). The Measurement of student engagement: A comparative analysis of various methods and student self-report instruments. S.L. Christenson et al. (eds.), Handbook of Research on Student Engagement, 763-782.

Gilboy, M. B., Heinerichs, S., and Pazzaglia, G. (2015). Enhancing student engagement using the flipped classroom. Journal of Nutrition Education and Behavior, 47 (1), 109-114.

Hazel Christie \& Nina Morris (2019). Using assessed blogs to enhance student engagement. Teaching in Higher Education, DOI: 10.1080/13562517.2019.1662390.

Holloway, I. and Todres, L. (2003). The status of method: Flexibility, consistency and coherence. Qualitative Research, 3 (3), 345-357.

Kahn, P. E. (2014). Theorising student engagement in higher education. British Educational Research Journal, 40 (6), 1005-1018.

Kahu, E. R. (2013). Framing student engagement in higher education. Studies in Higher Education, 38 (5), 758-773.

Kuh, G. D. (2009). The national survey of student engagement: Conceptual and empirical foundations. New Directions for Institutional Research, 141, 5-20. doi:10.1002/ir.283

Kuh, G. D., Kinzie, J., Schuh, J.H. and Whitt, E. J. (2005). Student success in college: Creating conditions that matter. San Francisco, CA: Jossey Bass

Lam, S., Wong, B., Yang, H., and Yi, L. (2012). Understanding student engagement with a contextual model. In S. L. Christenson, A. L. Reschly and C. Wylie (Eds.), Handbook of Research on Student Engagement. New York: Springer.

Lawson, M. A. and Lawson, H. A. (2013). New conceptual frameworks for student engagement research, policy and practice. Review of Educational Research, 83 (3), 432-479.

Leach, L. (2016). Enhancing student engagement in one institution. Journal of Further and Higher Education, 40 (1), 23-47.

Martin, A., Tarnanen, M., and Tynjala, P. (2018). Exploring teachers' stories of writing: A narrative perspective. Teachers and Teaching: Theory and Practice, 24 (6), 690-705.

Martin, K., Goldwasser, M., and Galentino, R. (2017). Impact of cohort bonds on student satisfaction and engagement. Current Issues in Education, 19 (3), 1-14. 
Matos, I., Reeve, J., Herrera, D., and Claux, M. (2018). Students' agentic engagement predicts longitudinal increases in perceived autonomy-ssupportive teaching: the squeaky wheel gets the grease. Journal of Experimental Education, 86 (4), 592-609.

Patton, M.Q. (2002). Qualitative research and evaluation methods, (3rd ed.) Thousand Oaks: Sage.

Pellas, N. (2014). The influence of computer self-efficacy, metacognitive self-regulation, and self-esteem on student engagement in online learning programs: Evidence from the virtual world of second life. Computers in Human Behavior, 35, 157-170.

Perini, M.R. (2016). Digital tools for learning, engagement, and research: An argument for student affairs and academic libraries. Global Journal of Human-Social Science Research, 15 (12), 43-50.

Pietkiewicz, I. and Smith, J. A. (2014). A practical guide to using interpretative phenomenological analysis in qualitative research psychology. Psychological Journal, 20 (1), 7-14.

Pringle, J., Drummond, J., McLafferty, E. and Hendry, C. (2011). Interpretative phenomenological analysis: A discussion and critique. Nurse Researcher, 18 (3), $20-$ 24.

Quin, D. (2017). Longitudinal and contextual associations between teacher-student relationships and student engagement. Review of Educational Research, 87 (2), 345387.

Reeve, J. (2012). A self-determination theory perspective on student engagement. In Christenson, S. L., Reschly, A. L. and Wylie, C. (Eds.), Handbook of research on student engagement. Boston: Springer.

Reschly, A. L. and Christenson, S. L. (2012). Jingle, jangle, and conceptual haziness: evolution and future directions of the engagement construct. In Christenson, S. L., Reschly, A. L. and Wylie, C. (Eds.), Handbook of research on student engagement. Boston: Springer.

Saini, D. and Chaudhary, N.S. (2019). What drives research in higher education? An Indian context. Journal of Applied Research in Higher Education. doi: 10.1108/JARHE-072018-0157.

Schlechty, P. C. (2004). Shaking up the schollhouse: How to support and sustain educational innovation. Indianapolis: Jossey-Bass. 
Smith, J. A. (2003). Qualitative psychology: A practical guide to research methods. London: Sage

Smith, J. A. (2004). Reflecting on the development of interpretative phenomenological analysis and its contribution to qualitative research in psychology. Qualitative Research in Psychology, 1 (1), 39-54.

Smith, A.C. (2011). Role ambiguity and role conflict in nurse case managers: An integrative review. Professional Case Management, 16 (4), 182-196.

Smith, J. A. and Osborn, M. (2008). Interpretative phenomenological analysis. in Smith, J.A. (Ed.), Qualitative Psychology: A Practical Guide to Research Methods. London: Sage

Smith, J. A., Flowers, P., \& Larkin, M. (2009). Interpretative phenomenological analysis: Theory, method and research. Los Angeles: Sage.

Tight, M. P. (2019). Student Retention and Engagement in Higher Education. Journal of Further and Higher Education, 1-16. doi:10.1080/0309877X.2019.1576860

VanScoy, A. and Evenstad, S. B. (2015). Interpretative phenomenological analysis for LIS research. Journal of Documentation. 71 (2), 338-357.

Wang, M. and Holcombe, R. (2010). Adolescents' perceptions of school environment, engagement, and academic achievement in middle school. American Educational Research Journal, 47 (3), 633-662.

Wimpenny, K., and Savin-Baden, M. (2013). Alienation, agency, and authenticity: A synthesis of the literature on student engagement. Teaching in Higher Education, 18 (3) pp. 311326.

Zepke, N. (2017). Student engagement in neoliberal times: Theories and practices for learning and teaching in higher education. Singapore: Springer,

Zepke, N. (2018). Student engagement in neo-liberal times: What is missing? Higher Education Research and Development, 37 (2), 433-446.

Zepke, N. and Leach, L. (2010). Improving student engagement: Ten Proposal for action. Active Learning in Higher Education, 11 (3), 167-177. 